\author{
Natalia Wiktoria Greniewska \\ Uniwersytet Warszawski, Warszawa
}

\title{
Tradycyjna biżuteria tybetańska
}

Biżuteria tybetańska od kilku dekad cieszy się coraz większym zainteresowaniem badaczy, czego rezultatem są bogato ilustrowane książki, różnego rodzaju opracowania oraz katalogi wydawane przez muzea na całym świecie. Liczne współczesne fotografie, filmy czy relacje podróżników potwierdzają, że biżuteria tybetańska jest elementem wciąż żywej tradycji. Do dzisiaj można spotkać (głównie na emigracji) tybetańskich artystów-rzemieślników, którzy niegdyś pracowali na zlecenie rządu i przeorów najważniejszych świątyń w kraju. Wszystko to pozwala na wnikliwą analizę zagadnienia.

Mówiąc o zasięgu kulturowym Tybetu, rozważamy teren znacznie bardziej rozległy niż tylko ten należący administracyjnie do Chińskiej Republiki Ludowej. Poza okupowanym obszarem (Tybetański Region Autonomiczny, część Syczuanu, Yunnanu, Qinghaiu i Gansu) z tradycją tybetańską możemy spotkać się również w Indiach, głównie w Sikkimie, Ladakhu, Spiti, Himachal Pradesz czy Arunachal Pradesz, w Nepalu (w królestwie Mustangu) czy Bhutanie. Tradycyjna biżuteria tybetańska jest także wykonywana przez Tybetańczyków na wychodźstwie, głównie w Stanach Zjednoczonych, Kanadzie, Australii, Szwajcarii czy Norwegii.

Tło historyczne jest niezwykle bogate i nie sposób go nakreślić nawet na kilku stronach, niemniej warto wspomnieć o kilku faktach, które miały znaczący wpływ na rzemiosło tybetańskie. Były to m.in. relacje wpływów i wymiany wzorów z sąsiadami, czego przykładem jest ornamentyka widoczna w zabytkach archeologicznych metaloplastyki scytyjskiej z IV-III w. p.n.e. W kolejnych wiekach, tj. w VI-VII w. n.e., wyraźny wpływ na rękodzielnictwo wywarła sztuka 
indyjska, nepalska, chińska, a także z terenów Kaszmiru, Chotanu, Kaszgaru i Gandhary. Ogromne znaczenie dla rozwoju biżuterii tybetańskiej miał Jedwabny Szlak, dawna droga handlowa łącząca Chiny z Europą i Bliskim Wschodem, która pozwoliła na wprowadzenie nowych metod i technik oraz sprowadzenie nieznanych wcześniej materiałów, jak również umożliwiła napływ wykwalifikowanych i utalentowanych rzemieślników. Ekspansja militarna Tybetu w VII-IX w. także ułatwiła kontakty z wieloma kulturami i zapoznanie się z ciekawymi metodami wytwarzania biżuterii oraz unikatowym wzornictwem. Sztuka zdobnicza od VII w. związana była z buddyzmem, co wpłynęło na stylistykę tradycyjnej biżuterii. Wiek XII był czasem wpływów wynikających z działalności Mongołów. Do XVII w. Tybetańczycy zapraszali do swojego kraju wielu zagranicznych rzemieślników, co pozwoliło na poznanie nowych technik i motywów, przyniosło również nowe inspiracje. Natomiast od XVII w. Tybet znajdował się w obszarze zainteresowań cesarzy z mandżurskiej dynastii Qing, co skutkowało ponownym pojawieniem się sztuki sino-tybetańskiej oraz tworzeniem wyrobów artystycznych o charakterze synkretycznym. Od momentu wejścia do Tybetu wojsk Chińskiej Armii Ludowo-Wyzwoleńczej w 1950 r. rozpoczęło się wyniszczanie kultury i sztuki tybetańskiej. Rewolucja kulturalna 1966-76 na zawsze pochłonęła wiele dzieł twórczości artystycznej, również tej rękodzielniczej. Sztuka socrealizmu, której stylistyka zaczęła obowiązywać na całym terenie Chińskiej Republiki Ludowej, stała się widoczna w wyrobach tybetańskich. Szczęśliwie tradycyjne metody i style rękodzieła tybetańskiego są kontynuowane na wychodźstwie, głównie w Indiach i Nepalu.

Biżuterię tybetańską wyróżniają bogate formy, pełne przepychu i koloru. Charakteryzują ją różne style w zależności od regionu. Można tu mówić w szczególności o stylu z Lhasy, stylu Tybetu Zachodniego i Ladakhu, stylu wschodnim oraz stylu centralnym i południowym. Tybetanki zakładały przede wszystkim ozdoby na głowę i włosy, szereg naszyjników i napierśników, kolczyki, bransolety oraz pierścionki, wplatane również we włosy. Dla mężczyzn charakterystyczne były szkaplerzyki, nawet do kilkunastu sztuk noszonych naraz (Clark 2008: 16), amulety wplatane we włosy, pierścienie oraz kolczyki, pasy i kunsztownie zdobiona broń. Biżuteria tybetańska wskazuje na region, z którego pochodzi jego właściciel, jego płeć, pozycję w społeczeństwie i majętność (Clark 1996: 839), pozwala również określić jego wierzenia. Poza funkcją dekoracyjną zapewnia także ochronę przed złymi mocami. Urzędnicy nosili czapki zwieńczone guzami z kamieni szlachetnych, co zostało 
narzucone przez administrację mandżurską. Innym symbolem tybetańskich oficjeli $\mathrm{z}$ Lhasy był podłużny kolczyk, zawieszany w jednym uchu (Clark 2008: 17). Okrągłe srebrne kolczyki, wysadzane perłami i turkusami należały do kupców i zamożnych rolników z Tybetu środkowego (Clark 1996: 839). Im mieszkaniec Tybetu był bogatszy, tym bardziej wymyślne i droższe były jego ozdoby. Żony najbogatszych kupców w południowym Tybecie nosiły rozpięte na obręczach przybrania głowy, wysadzane koralami i turkusami oraz owijane sznurami pereł (Clark 2008: 16). Całość stanowiła efektowną konstrukcję o strukturze przypominającej nieco pajęczą sieć. Biżuteria wykonana z metali szlachetnych przynosiła szczęście, a niektóre ozdoby stosowano jak amulety. W południowym Tybecie przyjął się zwyczaj, że brak ozdób we włosach u kobiet przynosi pecha, co powodowało, że jeszcze w połowie ubiegłego stulecia kobiety w nich nawet spały. Wyjątkiem był tylko czas żałoby (tamże: 15). Wierzono również, że podarowanie kobiecie kamieni szlachetnych w trakcie zaręczyn będzie chronić jej nienarodzone dziecko (tamże). Z kolei mężczyźni nosili na kciuku lewej dłoni pierścienie $\mathrm{z}$ kości słoniowej, które miały ich uchronić przed wiedźmami (tamże). Przekłute uszy miały zabezpieczać przed reinkarnacją w takie zwierzęta jak osły, powszechne więc było noszenie kolczyków również przez mężczyzn (tamże). Zazwyczaj nosili oni okrągły kolczyk w lewym uchu, prawe natomiast zdobił pojedynczy turkus (Clark 1996: 839).

Według Schuylera Van Rensselaer Cammanna, strój tybetański jest różny $\mathrm{w}$ zależności od grupy. Arystokraci oraz urzędnicy $\mathrm{z}$ Lhasy upinali włosy w koki na czubku głowy i przymocowywali do nich amulety. Dawniej wielu mężczyzn goliło głowy, zostawiając długie kucyki, które przewlekali przez pierścienie srebrne bądź z kości słoniowej i oplatali je wokół głowy. Kobiety z Lhasy nosiły w poprzek głowy poziomą listwę pokrytą materiałem i udekorowaną koralami i klejnotami wiszącymi na łańcuszkach. W Szigace ${ }^{1}$ drewniany łuk służył jako podpora do rozciągania nitek z koralikami (Van Rensselaer Cammann 1961: 29-30). Mimo iż zdobienia głowy $\mathrm{z}$ południowego i środkowego Tybetu różnią się znacznie, to $\mathrm{w}$ obu przypadkach podstawą konstrukcji jest drewno otulone filcem i zdobione koralami, turkusami oraz perłami (Clark 1996: 840). Bez względu na region kobiece zestawy zawieszane wokół głowy były ciężkie, dlatego często ozdoby wiszące wzdłuż skroni dodatkowo

${ }^{1}$ Miasto na prawach prefektury w południowej części Tybetańskiego Regionu Autonomicznego w Chinach. 
mocowano do taśmy wokół głowy. Nakrycie głowy z Ladakhu ${ }^{2}$, zwane perakiem, jest prawdopodobnie największą i najcięższą (około $2 \mathrm{~kg}$ ) tego rodzaju ozdobą na świecie (Dzikowska 2014: 9). Takie przybranie miało zapewnić kobietom przychylność bóstw wężowych (nagów), w tym płodność. Do dziś uważa się, że bez peraku kobieta narażona jest na bezpłodność. Współcześnie perak często składa się ze sztucznych turkusów, podczas gdy w przeszłości stanowił majątek kobiety, którym mogła swobodnie dysponować.

Do dzisiaj Tybetańczycy wierzą w magiczną moc amuletów i szkaplerzyków (gau). Istnieje wiele typów amuletów, zależnych od czterech rodzajów aktywności (uspokojenia, rozwoju, podporządkowania oraz gniewu) (Skorupski 2009: 11), poświęconych różnym bóstwom i demonom. Zawierają one różne mantry, a jedną z częściej stosowanych jest modlitwa om mani padme

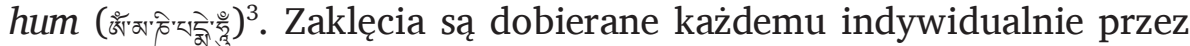
lamę. Każda Tybetanka, majętna czy uboga, nosiła na piersiach zazwyczaj złoty szkaplerzyk, wysadzany turkusami i zawierający modlitwę bądź zaklęcie zapisane na kawałku papieru. Tybetańczycy częściej nosili grawerowane kasetki wykonane z mosiądzu bądź srebra. Zawieszali je na szyi, a te mniej poręczne dźwigali za nimi służący (Skorupski 2009: viii, ix, za: Hayden 1928: 114-115). Mężczyźni trzymali je również przewieszone przez lewe ramię, na boku (Clark 2008: 16). Były zakładane zwłaszcza w podróży (Tucci 1967: 80), by odgonić złe duchy napotkane po drodze. Szkaplerzyki wysadzano turkusami i koralami, przestrzeń pomiędzy kamieniami wypełniano zwojami $\mathrm{w}$ technice filigranu. Dodatkowo czasami kamienie bądź krawędzie pudełeczek były otaczane perłowymi sznurami (Clark 1996: 840). Kształt szkaplerzyków zależy od regionu, w którym się go wykonuje, w Lhasie są one kwadratowe bądź w kształcie gwiazdy, na zachodzie kraju i przy granicy nepalskiej - prostokątne, zakończone łukiem (tamże).

Poza biżuterią apotropaiczną Tybetańczycy stosują wiele rodzajów biżuterii rytualnej. Warto tu wspomnieć o ozdobach kościanych płytkach noszonych na piersiach, używanych podczas różnych rytuałów, w szczególności egzorcyzmów. Wykonuje się je z kości, dawniej również ludzkich, w których rzeźbi się bóstwa tantryczne,

\footnotetext{
${ }^{2}$ Ladakh - kraina pomiędzy głównym pasmem Himalajów a górami Karakorum, położona w części górnego biegu rzeki Indus. Geograficznie najbardziej na zachód wysunięty fragment Wyżyny Tybetańskiej; historyczny Tybet Zachodni.

${ }^{3}$ Buddyjska sześciosylabowa mantra bodhisattwy współczucia, Awalokiteśwary.
} 
a następnie łączy za pomocą sznurka (Tucci 1967: 80). Również stroje używane do rytualnego tańca $\mathrm{cam}^{4}$ są bardzo bogato zdobione, a mnisi biorący udział $\mathrm{w}$ tym obrzędzie, $\mathrm{w}$ zależności od postaci, która wciela się $\mathrm{w}$ nich podczas tańca-obrzędu, nakładają wiele warstw naszyjników i amuletów. Świątynie buddyjskie skrywają w swoich wnętrzach liczne przykłady pięknej biżuterii. Obficie ozdabia się posągi bóstw, co ułatwia ich identyfikację i wskazuje na genezę stosowanych wzorów (Dzikowska 2014: 8).

Jedną z cech biżuterii tybetańskiej jest obfite używanie turkusu, zarówno wydobywanego na terenie Wyżyny Tybetańskiej, jak i importowanego z Iranu, oraz koralu przywożonego z Iranu i basenu Morza Śródziemnego, w oprawie z grubego srebra. Turkus naturalnie występujący w Tybecie ma niezwykłą barwę - zielonkawy błękit przetykany żyłkami, natomiast ten sprowadzany $\mathrm{z}$ Iranu jest niebieski. W naszyjnikach i kolczykach stosowano bałtycki bursztyn oraz śródziemnomorskie i indyjskie perły. Innym ważnym minerałem jest biało-czarny kamień gzi (onyks), któremu przypisuje się święte pochodzenie i zdolność do ochrony przed atakiem złych duchów (Clark 1996: 839). Czasem nazywa się go „okiem Buddy”, ze względu na występujące $\mathrm{w}$ nim na zmianę ciemne i jasne koła. Stosowany w amuletach ma zapewnić pomyślność, sławę i długowieczność oraz chronić od chorób, uroków i złych duchów (Dzikowska 2014: 38). Jego pochodzenie nie jest do końca jasne i związane są z nim liczne tybetańskie legendy przekazywane od wieków w tradycji ustnej. W jednej z nich gzi przedstawione są jako owady, które niegdyś żyły pod ziemią, jednak po dotknięciu przez człowieka zamieniły się w kamienie. Inna mówi o tym, że kamień został zesłany przez Buddę, aby pomóc Tybetańczykom pokonać dotkliwe klęski żywiołowe i epidemie ${ }^{5}$. Spośród metali często stosowano srebro, ale nie tylko. Lhasa była znana przede wszystkim ze swoich złotych wyrobów (Clark 2008: 44). Tybetańczycy, handlując z innymi krajami, często stosowali barter $\mathrm{z}$ powodu niewystarczającej ilości srebra do wybijania monet (Boyer 1952: 170).

Wpływ na style i techniki stosowane w Tybecie miały otaczające go państwa - Indie, Chiny czy Nepal. Dotyczy to również motywów dekoracyjnych, do których należą głównie zwierzęta i pomyślne zna-

\footnotetext{
${ }^{4}$ Tradycyjne tybetańskie tańce $\mathrm{w}$ maskach, wywodzące się $\mathrm{z}$ przedbuddyjskiej religii bön, lecz zarazem stanowiące rytuał $\mathrm{w}$ ramach buddyzmu tybetańskiego.

${ }^{5} \mathrm{http}: / /$ dzicrystal.com/articles/dzi-beads/5-the-legend-of-tibetan-dzi-bead [dostęp: 11.09.2016].
} 
ki, takie jak garuda ${ }^{6}$, jeleń, wadżra ${ }^{7}$ czy błyskawica (Clark 1996: 839). Symbolika buddyjska jest najczęściej spotykaną w rękodziełach, jednak jest to temat zbyt szeroki na artykuł tych rozmiarów, dlatego poniżej zostanie jedynie skrótowo przedstawione osiem zna-

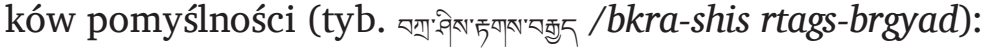

- koło dharmy (冷这/'khor-lo) - jest symbolem nauczania buddyjskiego, przypomina, że dharma jest kompletna sama w sobie, że nie ma początku ani końca, w tym samym momencie jest $\mathrm{w}$ ruchu i bezwładzie. Koło wyraża całkowitość nauczania i życzenie dalszego szerzenia nauk (Dagyab Rinpoche 1995: 30),

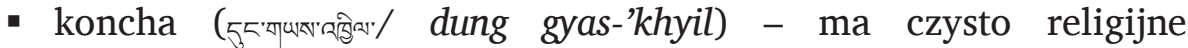
znaczenie, sławi nauczania Buddy (tamże: 24),

- kwiat lotosu (tyb. 떵 /padma) - jest symbolem czystości, boskiego pochodzenia i czystego umysłu (tamże: 23),

- parasol (tyb. गा5ुगत/ /gdugs) - przedmiot ten ma chronić przed surowym klimatem i złą pogodą, jest też symbolem siły (również duchowej) i wyższych warstw społecznych, w sferze religijnej ma chronić przez zbezczeszczeniem (tamże: 19),

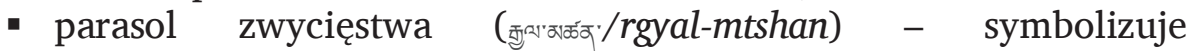
zwycięstwo nauczania Buddy, zwycięstwo wiedzy nad ignorancją oraz osiągnięcie szczęścia poprzez zwycięstwo nad wszelkimi przeszkodami (tamże: 27),

- ryby (खतेर־'/gser-nya) - Tybetańczycy nie przypisują temu znakowi żadnego specjalnego znaczenia (tamże: 21), jednak para ryb w dawnych tradycjach buddyjskich jest znakiem bogactwa oraz nadmiaru (Boyer 1952: 182),

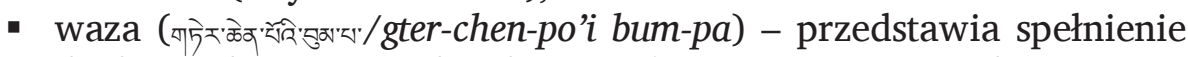
duchowych i materialnych życzeń, jest związana z bogactwem i posiadaniem paranormalnych umiejętności (Dagyab Rinpoche 1995: 22),

- węzeł nieskończoności (इचा सेक्रु/dpal be’u) - symbolizuje nieskończoną mądrość i wiedzę Buddy. Jest jednym z najczęściej występujących wzorów zdobniczych (tamże: 25).

\footnotetext{
${ }^{6}$ Mityczny ptak, jeden z wielu typów nieludzkich potężnych bytów w buddyzmie tybetańskim.

${ }^{7}$ Tyb. dordże ('diament, piorun'). Przedmiot rytualny w hinduizmie i buddyzmie. W buddyzmie tybetańskim stanowi on symbol stanu oświecenia, najwyższego poziomu rozwoju umysłu.
} 
Tybetańscy rzemieślnicy dzielą się na tych pracujących w ciągu całego roku oraz tych, którzy zajmują się kowalstwem okresowo, szczególnie w zimie, gdy nie mają dużo pracy związanej z uprawą roli. Wykonują oni zarówno narzędzia potrzebne w gospodarstwie, jak i biżuterię. Szczególnie cenni rękodzielnicy zamieszkują Tybet wschodni, regiony Derge i Dayab (Clark 2008: 43). Biżuteria tworzona $\mathrm{w}$ południowym i środkowym Tybecie również wymaga utalentowanych artystów. Dzieła wykonywane w prowincji Kham są uznawane za szczególnie piękne (Tucci 1967: 80). W dawnych czasach (przed ucieczką XIV Dalajlamy z Tybetu) rzemieślnicy najczęściej żyli w pobliżu świątyń, których przeorzy zlecali im pracę, i szlaków handlowych oraz na obrzeżach dużych ośrodków miejskich (Lhasa, Szigace). Do miast co roku przybywało wielu pielgrzymów, którzy zlecali wykonanie szeregu przedmiotów, zwykle rytualnych. Tradycyjnie tybetańscy artyści nie podpisywali swoich prac, rzadkim wyjątkiem mogły być dzieła religijne (Béguin 1996: 811).

Tybetańczycy przejęli z Indii uprzedzenie do kowali ze względu na wykonywanie przez nich przedmiotów, których użycie powodowało śmierć istot żywych. Natomiast złotników przyjmowano dużo lepiej, gdyż tworzyli przedmioty często o charakterze religijnym, z metali szlachetnych. Nie musieli nawet mieszkać na obrzeżach miasta, specjalną siedzibę mieli $\mathrm{w}$ pobliżu Potali ${ }^{8}$, pracując na zlecenie rządu (Clark 2008: 45-46).

Najczęściej stosowane techniki to kucie, wybijanie, wytłaczanie, grawerowanie, cyzelowanie, złocenie, platerowanie, filigran, granulacja czy inkrustacja (tamże: 46-48). Kolejność stosowanych technik, tj. odlewanie, wybijanie na cienkie płytki, następnie wycinane do uzyskania pożądanego kształtu i lutowane, nie różni się od tych występujących w całym rejonie Azji Środkowej. Do mocowania kamieni zazwyczaj stosowano klej, rzadziej osadzano je w trwalszy sposób (Boyer 1952: 178). Nierzadko rzeźbiono kamienie półszlachetne. Sztuki tej Tybetańczycy nauczyli się od Newarów, rękodzielników z Nepalu, którzy przybyli do Tybetu prawdopodobnie pod koniec XVII w. (Clark 2008: 49). Zapoznali oni Tybetańczyków również z mozaiką (Clark 1996: 839).

Tradycyjna biżuteria tybetańska jest tematem bardzo ciekawym zarówno ze względu na różnorodność wpływów i bogatą symbolikę buddyjską, jak i ze względu na jej estetykę. Warto jednak zaznaczyć, że można napotkać wiele problemów badawczych. Najważniejszy

\footnotetext{
${ }^{8}$ Pałac Potala - położona w Lhasiezimowa rezydencja nominalnych władców Tybetu do $1959 \mathrm{r}$.
} 
z nich spowodowany jest różnymi podejściami i perspektywami badawczymi związanymi z indywidualną postawą autorów wobec statusu obecnego Tybetańskiego Regionu Autonomicznego. Trudno dotrzeć do prawdziwych przykładów tradycyjnej biżuterii w Chinach, gdyż władze starają się pokazywać jej własną wersję. Z kolei w innych krajach, które zamieszkują Tybetańczycy, często można trafić na imitacje i podróbki prawdziwej biżuterii. Sporym problemem, zwłaszcza w Indiach i Nepalu, jest rękodzieło dla turystów, które z powodów głównie ekonomicznych jest wykonywane z kiepskiej jakości materiałów, często przez osoby bez odpowiedniego przeszkolenia, co przyczynia się do utraty zawodu przez prawdziwych artystów. Jednak coraz częściej kolejne pokolenia tybetańskich uchodźców, zwłaszcza w Ameryce czy krajach europejskich, zaczynają doceniać swoje dziedzictwo i starają się je szerzej promować na świecie.

\section{Bibliografia}

Béguin, Gilles. 1996. Tibet, §I, 7: Introduction: Artist and craftsman: Jane Turner (red.). The Dictionary of Art, vol. 30. New York: Grove.

Boyer, Martha 1952. Mongol Jewellery. I Komission Nos Gyldendalske Boghandel. København: Nordisk Forlag.

Clark, John. 1996. Tibet, §V, 5: Other arts: Jewellery: Jane Turner (red.). The Dictionary of Art, vol. 30. New York: Grove, 839.

Clark, John. 2008. Jewellery of Tibet and the Himalayas. London: V\&A Publications.

Dagyab Rinpoche, Loden Sherab. 1995. Buddhist Symbols in Tibetan Culture. Massachusetts: Wisdom Publications.

Dzikowska, Elżbieta. 2014. Biżuteria świata. Jewellery of the world. Pelplin: Bernardinum.

Meyers, Bernard S. (red.). 1961. Encyclopedia of World Art, vol. IV. New York: McGraw-Hill.

Meyers, Bernard S. (red). 1967. Encyclopedia of World Art, vol. XIV. New York: McGraw-Hill.

Rieff Anawalt, Patricia 2007. The Worldwide History of Dress. New York: Thames \& Hudson.

Skorupski, Tadeusz 2009. Tibetan Amulets. Bangkok: Orchid Press.

Talbot Rice, Tamara 1965. Ancient Arts of Central Asia. London: Thames \& Hudson.

Tucci, Giuseppe. 1967. Tibetan Art, Minor Arts and Handicrafts: Bernard Samuel Meyers (red.). Encyclopedia of World Art, vol. XIV. New York: McGraw-Hill, 80. 
Turner, Jane (red.). 1996. The Dictionary of Art, vol. 30. New York: Grove. Van Cutsem, Anne 2005. A World of Head Ornaments. Milano: Skira.

Abstract

\section{Traditional Tibetan jewellery}

The purpose of this paper is to present the phenomenon of Tibetan jewellery, its history, characteristics, styles, applied patterns and ornamentation. The work focuses on traditional jewellery, its application, execution methods, tools and materials used by jewellers, as well as on the symbolism, mainly Buddhist one, with broad meaning and often used during execution of the ornaments.

Keywords: jewellery, Tibet, craftsmanship, handicraft, adornment, ornament, tradition, decoration 